\title{
PPM Usaha Mikro Sambal Botolan Desa Mulung Gresik
}

\author{
Trisa Indrawati $^{1}$, Iful Novianto ${ }^{2}$, Andi Iswoyo ${ }^{3}$, Yanuar Fauzuddin ${ }^{4}$, Hendrik Rizqiawan ${ }^{5}$ \\ ${ }^{1}$ Universitas Wijaya Putra \\ ${ }^{2}$ Universitas Wijaya Putra \\ ${ }^{3}$ Universitas Wijaya Putra \\ ${ }^{4}$ Universitas Wijaya Putra \\ ${ }^{5}$ Universitas Wijaya Putra
}

indrawati@uwp.ac.id, ifulnovianto@uwp.ac.id, andi@uwp.ac.id, yanuarfauzuddin@uwp.ac.id, hendrikrizqiawan@ uwp.ac.id

\begin{abstract}
Abstrak
Pandemi Covid-19 merupakan hal yang tidak diduga akan terjadi dan mewabah hampir di seluruh belahan dunia pada tahun 2020. Pada data yang dirilis oleh WHO (World Health Organization), di akhir bulan Maret 2020 terdapat lebih dari 200 negara terjangkit virus Covid-19, termasuk Indonesia yang teridentifikasi terpapar virus Covid-19 per tanggal 02 Maret 2020. Pandemi Covid-19 menyebabkan masalah pelik bagi masyarakat, tidak terkecuali di Indonesia. Tidak sedikit aktivitas yang biasanya berjalan normal harus dihentikan, walaupun ada diantaranya yang mengalami penyesuaian, salah satunya adalah himbauan untuk beraktivitas dari rumah. Mitra yang merupakan wanita muda dari kabupaten Gresik ini memanfaatkan waktu luang di kala pandemi dengan memproduksi produk yang juga bermanfaat untuk meningkatkan imun, yaitu sambal botolan. Program ini bertujuan agar mitra mempunyai perlengkapan yang lebih sesuai dalam menjalankan usahanya tersebut, khususnya pada aspek pengemasan. Karena alat pengemasan sebelumnya masih belum dapat menutup sambal dengan sempurna, terkadang sambal menetes keluar yang mengakibatkan pelanggan komplain. Tujuan berikutnya, mitra dapat melakukan pencatatan keuangan dengan baik dan rutin, selama ini mitra mencatat pengeluaran dan pemasukan terkesan jika sempat saja. Program ini berlangsung pada bulan Juli hingga Agustus tahun 2021. Metode yang dilakukan berupa pemberian alat pengemasan berupa mesin induksi sealer beserta pendampingan cara penggunaan dan perawatannya, dan pelatihan pencatatan keuangan sebanyak 2 sesi.
\end{abstract}

Kata Kunci: Usaha Mikro, Pengusaha Muda, Makanan, Gresik

\section{PENDAHULUAN}

Pandemi Covid-19 merupakan hal yang tidak diduga akan terjadi dan mewabah hampir di seluruh belahan dunia pada tahun 2020. Pada data yang dirilis oleh WHO (World Health Organization), di akhir bulan Maret 2020 terdapat lebih dari 200 negara terjangkit virus Covid-19 $\left(\mathrm{WHO}^{1}\right.$, 2020), termasuk Indonesia yang teridentifikasi terpapar virus Covid-19 per tanggal
02 Maret $2020\left(\mathrm{WHO}^{2}, 2020\right)$. Pandemi Covid-19 menyebabkan masalah pelik bagi masyarakat di berbagai belahan dunia, tidak terkecuali di Indonesia. Tidak sedikit aktivitas yang biasanya berjalan normal harus dihentikan, walaupun ada diantaranya yang mengalami penyesuaian, salah satunya adalah himbauan untuk beraktivitas dari rumah. Mitra adalah seorang wanita yang memiliki nama lengkap Rizky Savira Ridwan dan berdomisil di desa Mulung kabupaten Gresik Jawa Timur ini 
memanfaatkan waktu luang di rumah di kala pandemi dengan memproduksi produk yang juga bermanfaat untuk meningkatkan imun, yaitu sambal botolan. Produk mitra yang berupa sambal botolan dengan bahan baku cabai memiliki kandungan vitamin yang cukup tinggi yang tentunya dapat berdampak pada penguatan imun tubuh. Sebagaimana hasil penelitian yang menyebutkan bahwa kadar vitamin C pada cabai rawit setelah dilakukan teknik pengawetan pada pendinginan yaitu $11,08 \mathrm{mg} / 100 \mathrm{~g}$ dan pada pengeringan yaitu $9,85 \mathrm{mg} / 100 \mathrm{~g}$ (Nurjannah, et. al., 2018). Selain cabai, beberapa rempah lain yang menjadi bahan baku juga dinilai memiliki manfaat yang baik pada tubuh. Seperti bawang merah yang mengandung senyawa fitokimia memiliki efek farmakologis dalam penyembuhan penyakit. Senyawa organosulfur pada bawang merah seperti kuersetin dan allisin juga bermanfaat dalam penghambatan infeksi virus (Balai Besar Penelitian dan Pengembangan Pascapanen Pertanian, 2020).

Sambal botolan yang mitra produksi terdiri dari berbagai varian, antara lain Sambal Teri Pedas, Sambal Tuna Cabe Ijo, Sambal Cumi Pedas Manis dan Sambal Cumi Pedas Nampol. Dengan berat isi sebesar 160 gram, mitra mematok harga dengan range mulai dari Rp. 20.000 hingga Rp. 30.000. Mitra menjalankan usaha tersebut dibantu oleh saudara dan orang tuanya. Mitra awalnya memulai usaha sambal botolan karena ingin coba-coba dalam rangka mengisi waktu yang luang di rumah di kala pandemi dan menawarkan kepada saudara dan teman dekat, namun respon yang dia dapatkan cukup positif yang diikuti banyaknya pesanan maka akhirnya mitra mantap menetapkan hati untuk menekuni usaha tersebut. Beberapa bulan awal berjalan usahanya, mitra hanya memproduksi sambal botolan yang bermerek Bu Ridwan tersebut jika ada pesanan saja. Namun menginjak 1 tahun usia usaha tersebut, mitra memberanikan diri untuk memproduksi lebih banyak dan menyediakan stok dengan kuantitas tertentu. Sambal botolan mitra memiliki ketahanan yang cukup lama, yaitu lebih dari 1 bulan. Mitra tidak memproduksi sambal botolan setiap hari, namun jika dirata-rata dalam satu bulan mitra dapat memproduksi sebanyak 60 sampai dengan 100 botol.
Mitra sedari awal sudah mempromosikan produknya menggunakan media digital yang menurutnya cukup efektif, seperti Whatsapp, Facebook hingga Instagram. Di Instagram sendiri, pengikut akun Produk Mitra berkisar ratusan dan memiliki postingan sebanyak dua puluh lebih. Di akun tersebut selain ditampilan gambar varian sambal botolan, mitra juga menampilkan bagaimana transaksi dan penjualan yang dapat dilakukan calon pembeli, seperti COD di area tertentu, akses ke marketplace yang tentunya memudahkan pembeli dari lokasi yang jauh dan sistem pembayarannya. Tentunya hal tersebut dapat meningkatkan penjualan mitra. Setiap bulan mitra berhasil menjual 60 hingga 70 botol sambal, bahkan pernah hingga 100 botol lebih. Tidak dipungkiri dalam selama menjalankan usahanya, ada beberapa permasalahan yang dihadapi oleh mitra. Permasalahan mitra antara lain terjadi pada bidang pengemasan produk, mitra melakukannya kurang sempurna. Produk mitra yang berupa sambal cenderung cair, sehingga jika tidak ditutup rapat dan tepat maka kadang kala merembes keluar, terlebih ketika dikirim menggunakan jasa ekspedisi. Kemudian pada bidang manajemen keuangan, mitra kurang tertib dalam melakukan pencatatan keuangan, baik ketika membeli bahan baku (uang keluar) dan ketika melakukan penjualan (uang masuk). Mitra juga sering kali kesulitan menghitung biaya produksi, yang akhirnya menentukan harga jual sebiasanya dan tidak dapat mengetahui berapa persisnya laba yang dihasilkan. Berdasarkan kondisi yang mitra alami tersebut, maka program pemberdayaan masyarakat atau dikenal dengan istilah PPM ini dilaksanakan dengan tujuan antara lain: 1) Mitra mempunyai perlengkapan yang lebih sesuai dalam menjalankan usahanya, khususnya pada aspek pengemasan. Karena alat pengemasan sebelumnya masih belum dapat menutup sambal dengan sempurna, terkadang sambal menetes keluar yang mengakibatkan pelanggan komplain; 2) Tujuan berikutnya, mitra dapat melakukan pencatatan keuangan dengan baik dan rutin, selama ini mitra mencatat pengeluaran dan pemasukan terkesan jika sempat saja.

\section{METODE}


Pelaksanaan program pemberdayaan masyarakat atau yang dikenal dengan PPM ini berlangsung pada bulan Juli hingga Agustus tahun 2021. Walaupun sempat terjadi PPM hingga level 4 baik di kabupaten Gresik maupun di kota Surabaya, namun program dapat terlaksana dengan maksimal. Selain pada setiap aktivitas yang membutuhkan kontak fisik dibarengi dengan mematuhi protokol kesehatan dengan baik, beberapa pelaksanaan program yang memungkinkan seperti pada pelatihan pencatatan keuangan, dilakukan dengan menggunakan media daring.

Rincian aktivitas program yang telah dijalankan antara lain: 1) Bidang pengemasan. Mitra mendapatkan alat pengemasan yang dapat menutup produk dengan rapat dan tepat. Alat tersebut berupa mesin induksi sealer (induction sealer machine) yang berfungsi untuk merekatkan alumunium foil pada botol sambal sebelum ditutup dengan tutup bergulir. Selain itu, mitra juga didampingi bagaimana cara pengoperasiannya dan bagaimana merawatnya dengan tepat; 2) Bidang manajemen keuangan. Mitra diberi pelatihan pencatatan keuangan sebanyak 2 sesi menggunakan media daring. Sebelumnya mitra sudah diberi perlengkapan pencatatan keuangan seperti buku keuangan dan kalkulator guna mengkalkulasi biaya produksi maupun penghitungan lainnya yang terkait usahanya (semisal ketika membeli bahan baku dan melakukan penjualan).

\section{HASIL DAN PEMBAHASAN}

\section{1 Pendampingan Bidang Pengemasan Produk}

Sambal botol $\mathrm{Bu}$ Ridwan yang diproduksi oleh mitra menggunakan kemasan berbahan baku plastik. Sebelumnya, setelah melakukan pengisian sambal ke dalam botol, proses pengemasan dilakukan dengan menutup botol tersebut dengan plug atau sumpal yang juga berasal dari plastik, lalu ditutup dengan tutup bergulir. Kemudian proses terakhir dalam pengemasan berupa penyegelan bagian luar atas botol menggunakan plastik tipis yang dipanaskan dengan hot gun. Namun ternyata, cara pengemasan tersebut kurang efektif. Produk mitra yang berupa sambal cenderung cair, terkadang plug/sumpal plastik yang telah ditutup di bagian dalam botol tidak tertututp dengan baik, maka cairan sambal merembes keluar. Walaupun sudah disegel menggunakan plastik di bagian luar, rembesan tetap terjadi, terlebih ketika sambal botol Bu Ridwan dikirim menggunakan jasa ekspedisi.

Dengan adanya mesin induksi sealer (induction sealer machine) yang membutuhkan daya listrik hingga 600 watt, plug/sumpal plastik tidak dibutuhkan lagi. Plug/sumpal plastik telah digantikan oleh alumunium foil yang telah direkatkan dengan baik pada bibir botol sebelum ditutup dengan tutup bergulir. Beberapa kali hasil uji coba menunjukkan bahwa alumunium foil telah terekat dengan baik dan sambal tidak bocor walau dibolak-balik. Tentunya hal ini dapat membantu mitra dalam memasarkan produknya dengan lebih aman. Fungsi kemasan juga dapat berjalan sebagaimana mestinya. Kemasan pada produk memiliki berbagai peran, diantaranya melindungi produk (itu sendiri) dari kerusakan dan mempermudah pada proses distribusi atau pengangkutan transportasi (Sucipta et al., 2017). Penyegelan botol (baik berbahan baku plastik maupun kaca) menggunakan alumunium foil juga mampu menghasilkan kemasan produk tertutup rapat. Kemasan produk yang telah tertutup rapat tersebut dapat membuat produk lebih tahan lama dan terlindung dari kontaminasi (Yuliantoro, 2017).

Mesin induksi sealer (induction sealer machine) tersebut juga memiliki rentang diameter bibir botol dari $2 \mathrm{~cm}$ hingga $10 \mathrm{~cm}$, dan dapat disetting pengaturan panas dalam merekatkan alumunium foil pada bibir botol hingga beberapa level, sehingga jika mitra di kemudian hari berkeinginan menambah varian kemasan, alat tersebut masih dapat digunakan dengan maksimal. Bibir botol sambal botol Bu Ridwan yang mitra gunakan saat ini berdiameter $5 \mathrm{~cm}$. Pengoperasian mesin induksi sealer (induction sealer machine) terbilang mudah, setelah melakukan pengisian sambal ke dalam botol, bibir botol dipastikan kering (tidak ada minyak atau air) dan bersih, Lalu alumunium foil yang sesuai ukuran bibir botol dimasukkan ke dalam tutup botol bergulir dimana bagian sisi alumunium oilnya menghadap bawah/bibir botol (lembar alumunium foil terdiri 
dari 2 sisi, alumunium foil dan kertas), tutup digulirkan dengan rapat, kemudian handle mesin induksi sealer (induction sealer machine) yang memiliki bagian induction port diarahkan pada tutup botol (bagian atas). Proses induksi berjalan kurang lebih 1,6 hingga 1,7 detik dengan cara menekan tombol di handle.



Gambar 1. Pendampingan cara penggunaan dan perawatan mesin induksi sealer (induction sealer machine)

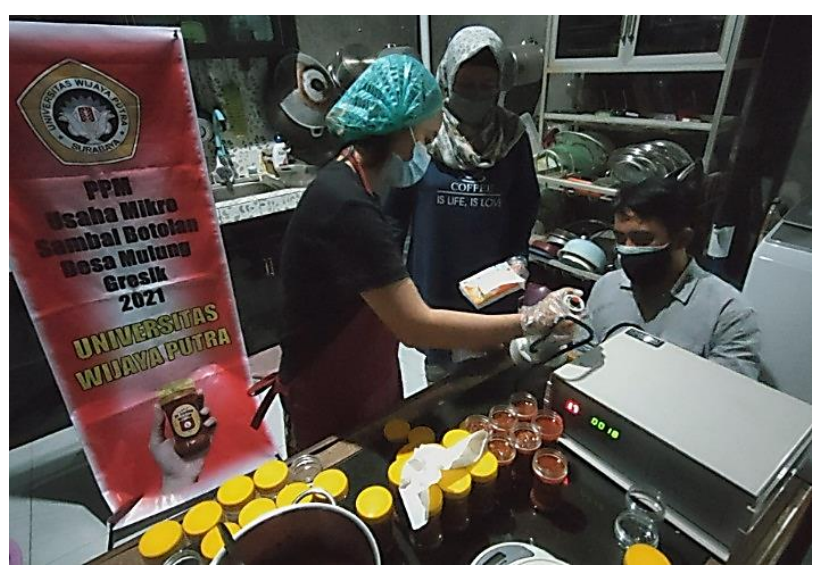

Gambar 2. Mendampingi mitra dalam menggunakan mesin induksi sealer (induction sealer machine)

\section{2 Pendampingan Bidang Manajemen Keuangan}

Mitra dalam mengelola keuangan usahanya, khususnya pada pencatatan keuangan, seringkali tidak dilakukan dengan tertib. Ketika membeli bahan baku (uang keluar) dan ketika melakukan penjualan (uang masuk), tidak selalu didata atau tercatat besaran nominalnya. Begitu juga waktu menentukan modal untuk produksi berikutnya. Akibatnya mitra tidak tahu dengan pasti besaran laba yang dihasilkan. Padahal, dengan melakukan pembukuan (pencatatan) keuangan yang baik dan tertib, maka mitra dapat meningkatkan pendapatannya. Kemampuan administrasi keuangan itu sendiri selaras dengan peningkatan penghasilan usaha kecil dan menengah atau UKM (Afkar et al., 2018).

Pelatihan dan pendampingan manajemen keuangan yang berupa pencatatan keuangan dilakukan sebanyak 2 sesi. Sesi pertama berupa pemberian informasi mengenai pentingnya pencatatan keuangan yang baik dan rutin, agar usaha dapat berjalan sesuai harapan. Pada sesi tersebut juga diserahterimakan perlengkapan pencatatan keuangan yang berupa buku keuangan dan kalkulator. Kemudian pada sesi kedua, pelatihan dilakukan melalui media daring yaitu Zoom. Dengan pelatihan dan pendampingan pembukuan (pencatatan) keuangan yang tepat, dapat membiasakan mitra mengelola aktivtas keuangannya dengan baik dan rutin atau tertib (Rizqiawan et al., 2020). Pendampingan manajemen keuangan bertujuan untuk memberikan pengarahan secara langsung jika mitra masih kesulitan dalam membuat pencatatan keuangan, namun jika mitra dianggap mampu melakukan pencatatan maka dilakukan koreksi atas pencatatan keuangan tersebut agar tidak terjadi kesalahan (Indrawati \& Karlin, 2019). Dan yang terjadi, mitra mampu melakukan pencatatan keuangan namun mitra kurang tertib dalam melakukannya. Sehingga pelatihan yang diberikan lebih pada penekanan pentingnya pencatatan keuangan dalam usaha dan mitra diberi saran untuk melakukan pencatatan keuangan pada berbagai media yang mudah diakses, seperti pada smartphone maupun laptop. 


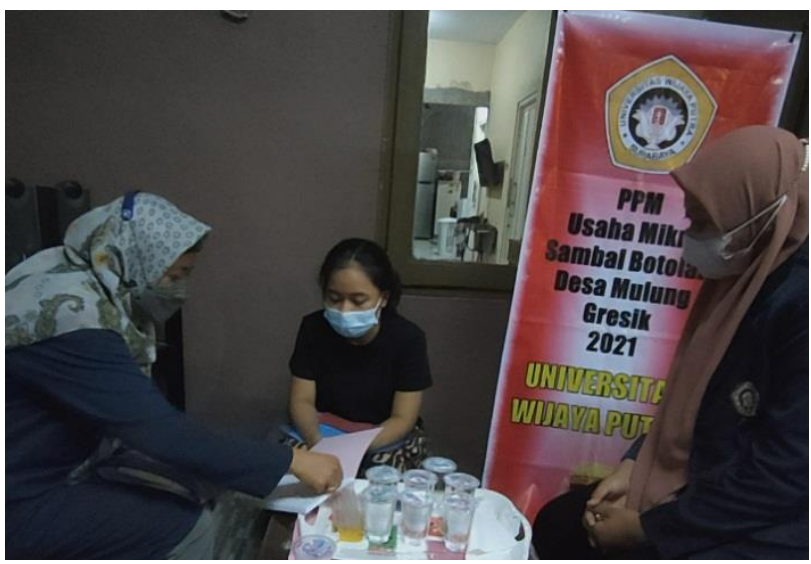

Gambar 3. Pendampingan bidang manajemen keuangan sesi 1

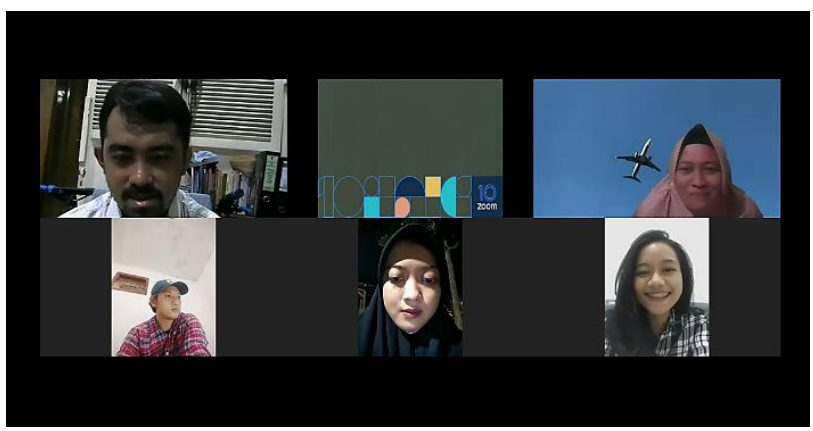

Gambar 4. Pendampingan bidang manajemen keuangan sesi 2 melalui media daring Zoom

\section{KESIMPULAN}

Pelaksanaan program pemberdayaan masyarakat atau yang dikenal dengan PPM ini berlangsung pada bulan Juli hingga Agustus tahun 2021. Dengan dua program pendampingan yaitu pendampingan bidang pengemasan dan pendampingan bidang manajemen keuangan. Mitra bersikap kooperatif dan cukup antusias atas pelaksanaan program ini. Mitra mempersilahkan rumahnya yang berlokasi di desa Mulung kabupaten Gresik Jawa Timur untuk dijadikan tempat pelaksanaan keseluruhan program yang membutuhkan kehadiran fisik (tatap muka langsung). Walaupun sempat terjadi PPM hingga level 4 baik di kabupaten Gresik maupun di kota Surabaya, namun program dapat terlaksana dengan maksimal. Selain pada setiap aktivitas yang membutuhkan kontak fisik dibarengi dengan mematuhi protokol kesehatan dengan baik (terlihat pada gambar 1, 2 dan 3 dimana masker selalu terpakai), beberapa pelaksanaan program yang memungkinkan dilakukan dengan menggunakan media daring, dilaksanakan menggunakan Zoom, seperti pada pelatihan pencatatan keuangan.

Pada pendampingan bidang pengemasan, saat ini mitra memiliki mesin induksi sealer (induction sealer machine). Mesin tersebut menjadikan pengemasan mitra semakin baik. Beberapa kali hasil uji coba pada program pendampingan menunjukkan bahwa alumunium foil telah terekat dengan baik dan sambal tidak bocor walau dibolak-balik. Mitra juga bisa mengoperasikan mesin induksi sealer (induction sealer machine) tersebut dan tahu bagaimana cara merawatnya dengan tepat Lalu pada pendampingan bidang manajemen keuangan. Ternyata mitra mampu melakukan pencatatan keuangan namun kerapkali tidak tertib dalam melakukannya. Sehingga pelatihan yang diberikan lebih pada penekanan pentingnya pencatatan keuangan dalam usaha dan mitra diberi saran untuk melakukan pencatatan keuangan pada media lain (selain buku) yang mudah diakses (sebagaimana pada gambar 4).

\section{UCAPAN TERIMAKASIH}

Kami haturkan terimakasih kepada Universitas Wijaya Putra surabaya, terkhusus Lembaga Penelitian dan Pengabdian kepada Masyarakat (LPPM) yang telah memberikan kesempatan dan dukungan kepada kami dalam rangka pelaksanaan program pemberdayaan masyarakat atau dikenal dengan istilah PPM ini.

\section{REFERENSI}

Afkar, T., Waryanto, R.B.D., \& Istikhoroh, S. (2018). Upaya Peningkatan Penghasilan UKM dengan Tertib Administrasi Keuangan di Desa Kenongo Kecamatan Tulangan Sidoarjo. AJIE - 
Asian Journal of Innovation and Entrepreneurship. 3(September): 351-357.

Indrawati, T. \& Karlin, K. (2019). Pemberdayaan Ibu-Bu Rumah Tangga Miskin Melalui Inkubasi Usaha Mandiri di Kecamatan Benowo Kota Surabaya. Prosiding PKM-CSR, 2(2019): 1218-1229. e-ISSN: 2655-3570.

Nurjannah, I., Sabang., S.M. \& Afadil, A. (2018). Analisis Kadar Vitamin C, Kalsium dan Posforus pada Cabai Rawit (Capsicum Frustescens 1.) Hasil Pengawetan. Jurnal Akademika Kimia. 7(4): 185-188.

Rizqiawan, H., Novianto, I. \& Subaderi, S. (2020). PKM Kelompok Usaha Ibu Rumah Tangga Kelurahan Lakarsantri Kota Surabaya. Journal Abdimas Musi Charitas, 4(2): 21-28.

Syamsuri, Prayudi, et. al. (2020). Buku Saku Bahan Pangan Potensial Untuk Anti Virus dan
Imun Booster. Bogor: Balai Besar Penelitian Dan Pengembangan Pascapanen Pertanian.

Sucipta, I.N., Suriasih, K., \& Kencana, P.K.D. (2017). Pengemasan Pangan - Kajian Pengemasan yang Aman, Nyaman, Efektif dan Efisien, Edisi Pertama. Denpasar: Udayana University Press.

Yuliantoro, Nonot. (2017). Pembotolan Sauce Sekunder Guna Menjaga Kualitas Rasa, Warna, Aroma dan Tekstur. Jurnal Khasanah Ilmu, 8(2). ISSN: $2087-0086$.

World Health Organization ${ }^{1}$. (2020). Coronavirus disease 2019 (COVID-19) Situation Report 71. In World Health Organization (Issue 71). World Health Organization ${ }^{2}$. (2020). Coronavirus disease 2019 (COVID-19) Situation Report 42. In World Health Organization (Issue 42). 